\title{
A NeW PERSPECTIVE ON THE PUBliC- PRIVATE DIVIDE? JUSTICIABILITY OF GOVERNMENT CONTRACTING DECISIONS FOLLOWING RIRINUI AND PROBLEM GAMBLING
}

\author{
Caleb $\mathrm{O}^{\prime} \mathrm{Fee}^{*}$
}

\begin{abstract}
Behind every theory of administrative law lies a theory of the state. Nowhere is this more apparent than in the application of judicial review to government contracting decisions. New Zealand courts have long struggled to adopt a consistent and coherent approach in this area, and two recent decisions of relevance do very little to improve the situation. This article argues that a decision of the Supreme Court in Ririnui significantly broadens the scope of justiciability of government contracting decisions by providing an exception to Mercury Energy. The Court of Appeal's approach in Problem Gambling is more cautious but has nevertheless resulted in a broadening of the range of circumstances where government contracting decisions will be subject to judicial review. Beyond these limited findings the law both in New Zealand and overseas continues to lack consistency and coherence. This article suggests that while this state of affairs is undoubtedly the result of the application of a public law cause of action to a context which sits on the public law-private law divide, the courts should stop relying on an inconsistent doctrine and recognise that cases are being decided on the basis of normative conceptions of the proper role of judicial review in this context.
\end{abstract}

\section{INTRODUCTION}

Two recent New Zealand cases that considered the justiciability of government contracting decisions have once again placed a spotlight on the role of judicial review in matters involving both public and private law. The first case, Ririnui v Landcorp Farming Ltd, signals a shift towards a broader approach to the justiciability of government contracting decisions and a clear shift away from the narrow formula espoused by Lord Templeman in Mercury Energy Ltd v Electricity Corporation

* Submitted as part of the LLB (Hons) programme at Victoria University of Wellington. I am very grateful to my supervisor, Dr Dean Knight, for all his support in writing this article. 
of New Zealand Ltd. ${ }^{1}$ In the second case - Attorney-General v Problem Gambling Foundation of New Zealand - the Court of Appeal has demonstrated an equal willingness to consider wider public interest implications when deciding on the correct scope of review in a government contracting context. ${ }^{2}$ However, beyond these limited findings, New Zealand's approach to the justiciability of government contracting decisions lacks consistency and coherence. This lack of consistency and coherence is not limited to New Zealand. The Canadian and English courts also have inconsistent jurisprudence in this area. $^{3}$

The courts' difficulty in this area has undoubtedly been exacerbated by the shift towards new public management. ${ }^{4}$ An integral part of this shift in New Zealand was the introduction of state-owned enterprises (SOEs), institutions that are required to operate as businesses which are as profitable and efficient as comparable businesses not under Crown ownership. ${ }^{5}$ The development of an institution which is created by statute but constrained by commerce was clearly in line with international trends towards "the era of mixed administration". ${ }^{6}$ However, this seismic shift brought with it difficult questions about the proper role of judicial review - an explicitly public law cause of action - in a context which engages both public and private law issues.

Theories of the state inform theories of administrative law. ${ }^{7}$ Accordingly, a court's conception of the proper role of judicial review in this context depends, at an abstract level, on broader theories of the state. ${ }^{8}$ These different theories of the state have resulted in different normative conceptions of administrative law in New Zealand. These normative differences determine whether judges will take a narrow or broad approach to the availability of judicial review in a government contracting context. This article suggests that it is ultimately these normative differences which are responsible for the

1 Ririnui v Landcorp Farming Ltd [2016] NZSC 62, [2016] 1 NZLR 1056; and Mercury Energy Ltd v Electricity Corporation of New Zealand Ltd [1994] 2 NZLR 385 (PC).

2 Attorney-General v Problem Gambling Foundation of New Zealand [2016] NZCA 609, [2017] 2 NZLR 470.

3 See Mark Elliott "Judicial Review's Scope, Foundation and Purposes: Joining the Dots" [2012] NZ L Rev 75 at 75 .

4 Janet McLean "New Public Management New Zealand Style" in PP Craig (ed) The Executive and Public Law (Oxford University Press, Oxford, 2006) 124 at 124. See also Michael Taggart "Corporatisation, Contracting and the Courts" (1994) PL 351 at 351; and Jason Varuhas Damages and Human Rights (Bloomsbury Publishing, London, 2016) at 173.

5 Taggart, above n 4, at 351; and State-Owned Enterprises Act 1986, s 4.

6 Varuhas, above $\mathrm{n}$ 4, at 173.

7 Carol Harlow and Richard Rawlings Law and Administration (3rd ed, Cambridge University Press, Cambridge, 2009) at 1.

8 Varuhas, above $\mathrm{n} 4$, at 171 . See also Harlow and Rawlings, above $\mathrm{n}$ 7, at 1. 
development of incoherent and inconsistent jurisprudence in this area. ${ }^{9}$ It concludes that the courts need to reject an incoherent doctrine and recognise that the availability of judicial review in each case will depend on a court's normative conception of its role in this context.

\section{RIRINUI: PUBLIC INTEREST IMPLICATIONS AND THE SCOPE OF REVIEW}

Ririnui is a landmark case which directly challenges the narrow bases on which government contracts can be reviewed. ${ }^{10}$ The majority finding rejects the finding in Mercury that government contracting decisions are only judicially reviewable in situations involving fraud, corruption or bad faith. Instead, where there is a significant public interest implication inherent in the contracting decision, the full panoply of judicial review grounds will be available. ${ }^{11}$ This article suggests that Ririnui should be interpreted as an exception to Mercury.

The case concerned the decision by Landcorp Farming Ltd to sell a farm, Whārere, over which Ngāti Whakahemo claimed mana whenua or demonstrated authority. ${ }^{12}$ Landcorp is an SOE set up under the State-Owned Enterprises Act 1986 (SOE Act) to manage a significant amount of former Crown-owned farmland. ${ }^{13}$ In accordance with a protocol agreed between Landcorp and the Office of Treaty Settlements (OTS), Landcorp contacted OTS to ask if Whārere would be used for any Treaty of Waitangi settlements in the future. ${ }^{14}$ The response from OTS was that it would not. ${ }^{15}$ It was subsequently admitted that Ngāti Whakahemo's Treaty claim in relation to Whārere had not been settled, and that OTS' view was therefore erroneous. ${ }^{16}$ Whārere was eventually sold by tender in 2013 to Micro Farms Ltd. ${ }^{17}$

In the High Court, Ngāti Whakahemo's case was advanced on a number of grounds. These included a claim that both Landcorp and its shareholding Ministers failed to comply with s 9 of the SOE Act and a further claim that the contract of sale was formed on the basis of OTS' invalid advice

9 See generally Elliott, above n 3.

10 Ririnui, above n 1.

11 Mark Elliott and Jason Varuhas Administrative Law: Text and Materials (Oxford University Press, Oxford, 2017) at 115 .

12 Ririnui, above n 1, at [2].

13 At [5].

14 At [6].

15 At [7] and [9].

16 At [53].

17 At [11] and [16]. 
and accordingly it "ought to be treated as fruit of a poisoned tree". ${ }^{18}$ Ngāti Whakahemo were unsuccessful in the High Court and Court of Appeal, so appealed to the Supreme Court, albeit on slightly different grounds. ${ }^{19}$ In the Supreme Court, three decisions were at issue. The first was the decision by Landcorp to enter into a sale and purchase agreement with the highest tenderer, Micro. ${ }^{20}$ The second concerned Landcorp's refusal to provide the undertaking sought by Ngāti Whakahemo, or to otherwise take steps to protect their position. ${ }^{21}$ The final decision was that made by the shareholding Ministers not to intervene on behalf of Ngāti Whakahemo as they had for Ngāti Mākino, another local iwi who, at the insistence of the shareholding Ministers, had been granted a first right of refusal to purchase Whārere. ${ }^{22}$

The majority issued a declaration that the decision by Landcorp to sell Whārere to Micro was a wrongful exercise of public power because it was made under a material mistake. ${ }^{23}$ In addition, Elias CJ and Arnold J would have referred the matter back to the shareholding Ministers to reconsider whether they would request Landcorp to give Ngāti Whakahemo the option to purchase Whārere at market price. ${ }^{24}$ However, neither Glazebrook nor O'Regan JJ were willing to grant such an order. ${ }^{25}$ Justice William Young held that the decision to sell Whārere to Micro was not "of a sufficiently public character to warrant judicial review". ${ }^{26}$ As a result of the Court's failure to set aside the contract of sale between Landcorp and Micro, or to otherwise refer the matter back to the shareholding Ministers, Ngāti Whakahemo in effect won the battle, but lost the war.

\section{A The Majority Decision}

The majority concluded that a court is unlikely to be able review the decision by a SOE to enter into a commercial contract in the absence of fraud, bad faith or some analogous situation, a proposition which was accepted by all parties. ${ }^{27}$ However, the majority ultimately circumvented Mercury in holding that the present case fell outside the general proposition because it was not an ordinary

18 Ririnui v Landcorp Farming Ltd [2014] NZHC 1128 at [99] and [148]. See also Ririnui v Landcorp Farming Ltd [2014] NZHC 3402 at [2] for a summary of the orders made by William J.

19 Ririnui v Landcorp Farming Ltd [2015] NZCA 160.

20 Ririnui, above n 1, at [63].

21 At [63].

22 At [63].

23 At [143] per Elias CJ and Arnold J.

24 At [142].

25 At [147] per Glazebrook J and at [192] per O'Regan J.

26 At [229] per William Young J.

27 At [65] per Elias CJ and Arnold J. 
commercial transaction. ${ }^{28}$ The majority suggested that it was not correct to describe the decision to offer Whārere to Ngāti Mākino - and by analogy the failure to make the same offer to Ngāti Whārere - as simply commercial in nature because there was a "substantial public interest component" to the decision. ${ }^{29}$ The public interest component centred on the sale of Whärere facilitating the obligation, incumbent on the Crown, to fulfil its obligations under the Treaty of Waitangi. ${ }^{30}$ The majority suggested that Landcorp's Statement of Corporate Intent evidenced a special relationship between Landcorp and the Crown whereby Landcorp would, in a broad sense, assist the Crown in fulfilling its Treaty obligations. ${ }^{31}$ Of particular relevance were several passages from the 2013-2016 Statement of Corporate Intent. Landcorp described its business activities therein as including the selling of nonstrategic properties where the particular land is sought by iwi. ${ }^{32}$ Reference is also made to the ability for Landcorp to seek compensation for retaining properties which might normally be intended for sale, but which are retained in case they are required by the Crown for Treaty settlements. ${ }^{33}$ Landcorp's decision to offer Whārere to Ngāti Mākino was, therefore, made pursuant to the Crown's Treaty obligations. The majority suggested that while the decision largely accommodated Landcorp's commercial interests, it was made for broader public interest reasons. ${ }^{34}$ Given this special Treaty context, the failure by Landcorp to make a similar offer to Ngāti Whakahemo was not merely commercial in nature and was furthermore premised on a material mistake as to the status of Ngāti Whakahemo's Treaty claim. ${ }^{35}$ This argument found support in Landcorp's statement in a deposition that it would not have sold Whārere if it thought that Ngāti Whakahemo had a credible Treaty claim in respect of it. ${ }^{36}$ Accordingly, the subsequent decision to sell Whārere to Micro was susceptible to review on broader grounds other than fraud, corruption, bad faith or something analogous. ${ }^{37}$

The majority engaged in a rather complex line of reasoning to circumvent the narrow formula espoused in Mercury. A similarly complex line of argument was drawn on by William Young $\mathrm{J}$ in an effort to dismiss Ngāti Whakahemo's claim. This divergence is explored further in Part IV, and a possible reason for it is outlined in Part V.

\footnotetext{
28 At [65].

29 At [71].

30 At [69].

31 At [66].

32 At [48].

33 At [48].

34 At [74].

35 At [98].

36 At [72].

37 At [98].
} 


\section{B The Minority Decision}

William Young J rejected Ngāti Whakahemo's claim on two grounds. The first centred on whether the decision to sell Whārere was "sufficiently public in nature" so as to warrant judicial review. ${ }^{38}$ The second concerned the application of s 21 of the SOE Act in light of the overall scheme of the Act. ${ }^{39}$ William Young $\mathbf{J}$, also critical of the approach in Mercury, suggested that the courts should adopt a more restricted approach to judicial review. The primary question would be whether the particular decision was "sufficiently public in character" so as to give rise to judicial review, ${ }^{40}$ a functional approach not unlike that espoused in $R v$ Panel on Take-Overs and Mergers, ex parte Datafin. ${ }^{41}$

Drawing on various factors, William Young J concluded that the decision by Landcorp to sell Whārere was not sufficiently public in character. ${ }^{42}$ He suggested that the purpose of s 4 of the SOE Act, which requires an SOE to be as profitable as comparable businesses not owned by the Crown, would be frustrated if the Court was to allow judicial review of the decision. ${ }^{43}$ Allowing judicial review in this context would similarly cut across the resumption provisions in the Act. ${ }^{44}$ In respect of the Treaty context, it was suggested that the relevant obligations were incumbent on the Crown, and the nature of the relationship between Landcorp and the Crown was such that it was not Landcorp's function to inquire beyond the Treaty advice given by OTS. ${ }^{45}$ In light of these factors, William Young J would not have allowed Landcorp's decision to sell Whārere to be judicially reviewed because it was not of a sufficiently public character.

38 At [213] per William Young J.

39 At [234].

40 At [213].

$41 R v$ Panel on Take-Overs and Mergers, ex parte Datafin [1987] QB 815 (CA) at 847. See also Jenny Cassie and Dean Knight "The Scope of Judicial Review: Who and What may be Reviewed?" (paper presented to NZLS CLE Administrative Law Intensive, Wellington, August 2007) at 66; and Laura Hardcastle "Can't See the Science for the Solicitors: Judicial Review of Scientific Research in Light of Niwa's Case" (2014) 12 NZJPIL 291 at 302-303.

42 Ririnui, above n 1, at [229].

43 At [217] and [231]. See also Wellington Regional Council v Post Office Bank Ltd HC Napier CP720-87, 5 July 1988 at 14; and Auckland Electric Power Board v Electricity Corporation of New Zealand Ltd [1994] 1 NZLR 551 (CA) [Mercury] at 558-560 (note that following the Court of Appeal's decision and prior to the case going to the Privy Council Auckland Electric Power Board's name was changed to Mercury Energy). For a contrary view see Michael Taggart "State-Owned Enterprises and Social Responsibility: A Contradiction in Terms" [1993] NZ Recent Law Review 343 at 349-352.

44 Ririnui, above n 1, at [219].

45 At [221]. 
In the alternative, William Young $\mathrm{J}$ considered s 21 of the SOE Act to be determinative of the case. ${ }^{46}$ This is directly contrary to the majority finding. Section 21 states that the failure by an SOE to comply with pt 1 of the Act or any statement of corporate intent will not affect the validity of any contract entered into by that SOE. ${ }^{47}$ Professor Michael Taggart argued that the legislative history of s 21 shows that Parliament did not intend the section to prevent the court's review powers where there has been a breach of pt $1 .^{48}$ The majority held that s 21 was not engaged because Ngāti Whakahemo's claim did not centre on Landcorp's non-compliance with the Act or its statement of corporate intent. ${ }^{49}$ Thus, the question of whether a judicial review claim could be brought on the basis of a breach of $\mathrm{pt}$ 1 was regrettably avoided. However, the majority did suggest that the purpose of s 21 is to prevent the contract being invalid on the basis of the SOE's non-compliance with pt 1 of the Act or its statement of corporate intent. ${ }^{50}$ This obiter statement - coupled with the explicit reference to Taggart's view - strongly suggests that judicial review will be available even in relation to a breach of pt 1 or a statement of corporate intent.

William Young J did not share this view. He argued that s 21 operates to preclude judicial review in relation to contracts entered into by SOEs. ${ }^{51}$ To allow third parties - in this case the courts - to challenge contracts entered into by an SOE on grounds otherwise unavailable to other commercial parties would be to put SOEs at a commercial disadvantage. ${ }^{52}$ In addition, William Young J suggested that the majority was wrong to conclude that Ngāti Whakahemo's claim was not based on Landcorp's failure to comply with pt 1 of the Act or the statement of corporate intent. He suggested that the majority's reference to the Crown's Treaty obligations amounted to an argument that s 9 had been breached. ${ }^{53}$ It must be noted that s 9 appears in pt 1 of the Act. ${ }^{54}$ Similarly, the majority's reference to the statement of corporate intent amounted to a suggestion that this statement had not been followed. ${ }^{55}$ In William Young J's view, s 21 would simply preclude the use of either argument to challenge a contract entered into by an SOE.

\author{
46 At [234]. \\ 47 State-Owned Enterprises Act, s 21. \\ 48 Taggart, above $\mathrm{n} 43$, at 353 . \\ 49 Ririnui, above n 1, at [116] per Elias CJ and Arnold J. \\ 50 At [117]. \\ 51 At [231] per William Young J. \\ 52 At [231]. \\ 53 At [232]. \\ 54 State-Owned Enterprises Act, s 9. \\ 55 Ririnui, above n 1, at [232].
}




\section{Reconciling Ririnui and Mercury}

Ririnui does not overrule Mercury but rather provides an exception to it. This, however, raises two further questions. The first is whether the majority of the Supreme Court needed to circumvent Mercury's narrow formula in this case. Mercury is not good law, and its strict application could result in a deserving claimant being left remediless. The second question is whether Ririnui improves the clarity or coherence of this legal doctrine any more than Mercury. This article argues that it does not. However, this lack of clarity and coherence is neither unique to these cases, nor to the New Zealand jurisdiction.

Mercury concerned a decision by the Electricity Corporation of New Zealand (ECNZ) to cancel a contract between it and Mercury Energy Ltd to supply bulk electricity. ${ }^{56}$ The case was eventually appealed to the Privy Council where Lord Templeman, delivering the advice, held that decisions of SOEs - insofar as they are made in the public interest - are amenable to judicial review both under the Judicature Amendment Act 1972 (now the Judicial Review Procedure Act 2016) and the common law. ${ }^{57}$ Although the Privy Council was willing to find that decisions of SOEs are in principle amenable to judicial review, the circumstances in which a court would be willing to inquire into such decisions would be limited to situations involving fraud, corruption and bad faith. ${ }^{58}$ It was suggested that Lord Templeman's approach at best resulted in further uncertainty surrounding the reviewability of contracting decisions by SOEs, and at worst "rendered the judgment internally inconsistent and ultimately hollow". 59

Undoubtedly conscious of the significant negative commentary surrounding Mercury, the majority in Ririnui side-stepped Lord Templeman's formula by holding that it did not apply to all contracting decisions by SOEs. ${ }^{60}$ In this case, the decision had a substantial public interest component to it giving rise to judicial review on principles broader than those outlined in Mercury. This article suggests that this was done deliberately on the basis that Ngāti Whakahemo were an innocent third party who, through no fault of their own, were about to lose their tribal lands. The absence of fraud, corruption or bad faith on the part of the Crown or Landcorp would have left the iwi unable to rely upon judicial review as a cause of action to protect their interest, and left them ultimately remediless.

56 Mercury, above n 1.

57 At 388

58 At 391

59 Taggart, above n 4, at 357. See also Janet McLean "Divergent Legal Conceptions of the State: Implications for Global Administrative Law" (2005) 68 LCP 167 at 185; and Kent N Phillips "Case Notes: Mercury Energy Ltd v Electricity Corporation of New Zealand Limited" (1994) 7 AULR 746 at 754.

60 Ririnui, above n 1, at [65]. 
The second issue is whether Ririnui adds any more clarity or coherence to this legal doctrine than Mercury. The majority decision in Ririnui failed to define the boundaries of the exception to Mercury, except to say that Mercury would not apply where there is a significant public interest implication. Precisely what qualifies as a "public interest implication" is not made clear. It is possible that the law was left unclear to open the possibilities for judicial review of government contracting in the future. By refusing to explicitly define the metes and bounds of this exception, the majority addressed the criticism levelled at the narrowness of Mercury. However, this is a double-edged sword. While such an approach addresses the narrowness critique, it serves to add more fuel to the fire for those commentators who criticised the Privy Council for failing to resolve this issue definitively when it first appeared more than 20 years ago. ${ }^{61}$ The Court of Appeal in Problem Gambling sought to clarify the issue by reconciling the approach in Ririnui with the approach adopted in Lab Tests Auckland Ltd $v$ Auckland District Health Board. ${ }^{62}$

\section{PROBLEM GAMBLING}

Attorney-General v Problem Gambling Foundation of New Zealand is a clear attempt by the Court of Appeal to interpret the broadened state of the law in the wake of Ririnui. ${ }^{63}$ The Court of Appeal has interpreted Ririnui as adding a further contextual factor to those outlined in Lab Tests. ${ }^{64}$ It remains to be seen whether this interpretation of Ririnui is correct. However, even if the Court of Appeal is found to have misinterpreted Ririnui, its addition of a "nature of the interest factor" to the Lab Tests contextual framework will nevertheless achieve the same result that the Supreme Court intended to achieve in Ririnui.

\section{A Facts and Holding}

The case concerned a request by the Ministry of Health for proposals (the RFP process) from private providers for the provision of problem gambling services in New Zealand. ${ }^{65}$ The Problem Gambling Foundation of New Zealand had provided problem gambling services since 1988 and had been the largest provider in New Zealand for 10 years. ${ }^{66}$ As a result of the RFP process, the Foundation lost a significant number of contracts to provide problem gambling services, and consequently had the scope of its services drastically reduced. ${ }^{67}$ Cognisant of the significant changes

61 See Taggart, above n 4, at 357; McLean, above n 59, at 185; and Phillips, above n 59, at 754.

62 Lab Tests Auckland Ltd v Auckland District Health Board [2008] NZCA 385, [2009] 1 NZLR 776.

63 Problem Gambling, above n 2.

64 Lab Tests, above n 62, at [55]-[59].

65 Problem Gambling, above n 2, at [1].

66 At [3] and [17].

67 At [21]. 
to the sector brought about by the RFP process, the Ministry sought additional reassurance from its external auditors that the process had been conducted with probity. ${ }^{6}$

Understandably disappointed with this outcome, the Foundation filed judicial review proceedings in the High Court alleging that the RFP process was flawed in a number of respects. Of importance was the fact that the suggested flaws in the process did not amount to allegations of fraud, corruption or bad faith. ${ }^{69}$ In the High Court, the Foundation was successful in reviewing the RFP process because it was able to avail itself of a broader scope of review. ${ }^{70}$ On appeal, the Court was unanimous in allowing the appeal and holding that a broader scope of review was not available. ${ }^{71}$

The Court, citing Lab Tests Auckland Ltd v Auckland District Health Board, held that the prima facie position in relation to commercial decisions will be that only narrow grounds of review will be available unless there are relevant contextual matters which justify a broader scope of review. ${ }^{72}$ Those contextual factors include the nature of the decision and decision-maker, as well as the statute empowering that decision. ${ }^{73}$ To these factors, the Court added the nature of the interest which is sought to be protected by the judicial review action. ${ }^{74}$ Where that interest is public in nature, the court may be entitled to adopt a broader scope of review in order to protect that interest. ${ }^{75}$ The Court agreed that the successful implementation of the Crown's problem gambling strategy did serve the public interest. ${ }^{76}$ However, the Foundation was denied the broader scope of review because - in the Court's view - it was merely a disappointed commercial party seeking to "take advantage of public law remedies in a commercial context". ${ }^{77}$

This is to be contrasted with the conclusion in Ririnui. The Court held that Ririnui was distinguishable on the basis that Ngāti Whakahemo's grievance directly aligned with the broader public interests at play. ${ }^{78}$ Put another way, there was a sufficient nexus between the claimant's

68 At [19].

69 At [27]

70 At [26]. For a discussion of the contextual factors justifying a broader scope of review see Problem Gambling Foundation of New Zealand v Attorney-General [2015] NZHC 1701 at [75]-[78] and [86]-[110].

71 Problem Gambling, above n 2, at [53].

72 At [41]; and Lab Tests, above n 62, at [55]-[59].

73 Problem Gambling, above n 2, at [34]. See also Lab Tests, above n 62, at [55]-[59].

74 Problem Gambling, above n 2, at [42].

75 At [42].

76 At [43].

77 At [42].

78 At [46]. 
grievance and the public interest. The question remains whether this is a correct interpretation of Ririnui.

\section{B Reconciling Ririnui and Problem Gambling}

Factually, Problem Gambling fits somewhat awkwardly alongside Ririnui and Mercury. At one end of the factual spectrum is Mercury, a case in which the impugned transaction was quite clearly of a commercial nature. At the other end of the spectrum is Ririnui, a case involving much broader considerations than merely commercial. Somewhere between the two is Problem Gambling, a case with a commercial flavour in the form of a government tendering process, but which nonetheless raised broader public issues around the contracting-out of health services. The Court of Appeal has clearly thought about the effect of Ririnui on the development of the legal doctrine in this area. In what must be considered an attempt to add some clarity to this area of the law, the Court held that Ririnui adds a contextual factor to those outlined in Lab Tests.

In Ririnui, the majority - on the basis of Mercury and Lab Tests - stated the general proposition that judicial review of contracting decisions will be available only in cases involving fraud, corruption, bad faith or analogous circumstances. ${ }^{79}$ However, the majority went on to say that Ririnui fell outside this general proposition on the basis that there was a significant public interest implication. ${ }^{80}$ The Court of Appeal, ostensibly on the basis of Ririnui, concluded that another contextual factor ought to be added to the Lab Tests framework. This factor was described as the nature of the interest that the claimant is seeking to protect. ${ }^{81}$ It is clear that, in adding this further contextual factor, the Court of Appeal was attempting to reconcile the Supreme Court's approach in Ririnui with the existing framework from Lab Tests.

The success of this reconciliation could perhaps be quantified by applying the Court of Appeal's approach in Problem Gambling to the facts of Ririnui. Indeed, the Court did make an obiter statement suggesting that Ngāti Whakahemo's grievance aligned with the broader public interest in the resolution of Treaty claims. ${ }^{82}$ Accordingly, the nature of this interest would have likely justified the adoption of a broad scope of review. Irrespective of whether this is a correct interpretation, the Court of Appeal's attempt to reconcile Ririnui with the existing law is practical and provides more guidance to decision-makers than the broad "public interest" exception propounded by the majority in Ririnui.

79 Ririnui, above n 1, at [65].

80 At [71].

81 Problem Gambling, above n 2, at [42].

82 At [46]. 


\section{THE STATE OF THE LAW}

This Part draws several threads together to analyse the state of the law in New Zealand in the wake of Ririnui and Problem Gambling. At this point, the following preliminary findings have been made. An analysis of the decision in Ririnui reveals an exception to the general rule regarding the justiciability of government contracting decisions. The Court of Appeal's approach to the same issue in Problem Gambling interprets Ririnui as adding a contextual factor to those outlined in Lab Tests. Beyond these limited findings, however, the state of the law in New Zealand is unclear. A broader analysis of both Ririnui and Problem Gambling as well as other New Zealand case law in this area discloses a significant divergence of judicial approaches. This is not an issue which is unique to New Zealand. Part V attempts to organise this divergence into two broad categories or approaches, each premised on a particular theory of the state.

\section{A Ririnui and Problem Gambling}

In Ririnui, the most significant divergence of opinion is that between the majority and William Young J. Both the majority and William Young J go to significant lengths to either uphold or dismiss Ngāti Whakahemo's claim. The majority approach circumvented the general proposition as outlined in Mercury by suggesting that the case before the Court was not an ordinary commercial transaction. ${ }^{83}$ The majority arrived at this conclusion on the basis of several pieces of evidence indicating a special relationship between Landcorp and the Crown in the context of Treaty settlements. ${ }^{84}$ In stark contrast William Young J disagreed, holding that Ngāti Whakahemo had no tenable judicial review claim. This conclusion was arrived at on two alternative bases. The first centred on whether the decision to sell Whārere was "sufficiently public in nature" so as to warrant judicial review. ${ }^{85}$ This point was not considered by the majority. The second concerned the application of s 21 of the SOE Act in light of the overall scheme of the Act. ${ }^{86}$ Again, the majority were unpersuaded by this point. It is rather difficult to understand how the same set of facts could have resulted in such a divergence of approaches in this case. When one also takes into consideration the approaches adopted in the High Court and Court of Appeal in this case, the matter becomes even more confusing. The approaches diverge to such an extent that when comparing the decision of the High Court to that of the Supreme Court, it is difficult to conceive of those decisions as being in the same case.

The same issue of divergence is to be found in Problem Gambling. The Court of Appeal were unanimous in their reasons for allowing the appeal and striking out all of the Foundation's claims. ${ }^{87}$

83 Ririnui, above n 1, at [71].

84 At [74].

85 At [213] per William Young J.

86 At [234].

87 See Problem Gambling, above n 2. 
However, the divergence appears when the Court of Appeal's approach is contrasted with that adopted by Woodhouse $\mathrm{J}$ in the High Court. Woodhouse $\mathrm{J}$ traversed the relevant authority in Lab Tests and Mercury and held that whether the scope of review is limited to fraud, corruption, bad faith or analogous circumstances depends on the context of the case. ${ }^{88}$ It was further held that the starting point in such matters is context; it is not the general proposition in Mercury, subject to context. ${ }^{89}$ The emphasis on context was considered to be necessary for two reasons. First, if judicial review was unavailable in a commercial context this would be directly contrary to established principles. ${ }^{90}$ Second, the court's references to "contracting decisions" and "commercial context" vary, and the precise definition in a given case depends on an analysis of the context. ${ }^{91}$ Justice Woodhouse reviewed a substantial number of contextual factors relevant to the case before him. ${ }^{92}$ On the basis of that contextual analysis, he arrived at the conclusion that a broad scope of review was available, and accordingly the decision was able to be reviewed on all of the grounds advanced by the Foundation. ${ }^{93}$

In contrast, the Court of Appeal cited the same authorities relied upon by Woodhouse $\mathbf{J}$ and came to the opposite conclusion. The Court held that the prima facie position will be that only narrow grounds of review are available, unless there are contextual factors indicating the need for broader powers of review. ${ }^{94}$ The Court then went on to consider and reject each of the contextual grounds identified by Woodhouse $\mathrm{J}$ as providing a justification for a broader scope of review. ${ }^{95}$ The Court appeared to be heavily persuaded by the fact that the Foundation was a commercial party which had just lost a significant commercial contract and drew the conclusion that it was merely a disappointed party trying to have a second bite of the cherry by way of judicial review. ${ }^{96}$ Again, it is difficult to see how the same factual circumstances in both the High Court and Court of Appeal in this case could justify the courts reaching such markedly different conclusions. Such significant divergence casts doubt on the ability of the courts to approach these issues in a consistent and principled way. If the net is cast a little wider to include other significant decisions in this context, the divergence of judicial approaches becomes even more apparent.

88 Problem Gambling, above n 70, at [61].

89 At [63].

90 At [62].

91 At [62].

92 At [75]-[78] and [86]-[110]

93 At [110].

94 Problem Gambling, above n 2, at [41].

95 At [43]-[53].

96 At [42]. See also Leah Heatley "Are Contractual Rights Amenable to Public Law Remedies?" (2016) 21 JR 253 at 260 . 


\section{B Other New Zealand Case Law}

Further evidence of the historically divergent approach to this issue in New Zealand can be found by comparing a line of authority where the courts have sought to broaden their ability to review commercial decisions with two cases where the courts have done the opposite. ${ }^{97}$ In Webster $v$ Auckland Harbour Board the courts sought to do the former. The Court of Appeal argued that public authorities have public law responsibilities, and accordingly it would be inappropriate to grant them unfettered discretion. ${ }^{98}$ In Royal Australasian College of Surgeons v Phipps the Court of Appeal followed the same line of reasoning in holding that a report into Mr Phipps's work could be judicially reviewed. ${ }^{99}$ The Court argued that in recent decades: ${ }^{100}$

Courts have increasingly been willing to review exercises of power which in substance are public or have important public consequences, however their origins and the persons or bodies exercising them might be

characterised ...

In Telco Technology Services Limited v Ministry of Education Collins J extended the availability of judicial review further to include decisions made in a commercial tendering context where the Crown may have breached procedural expectations to the detriment of a tenderer. ${ }^{101}$ In that case, the absence of statutory provisions regulating the tender process created a vacuum which could be filled by public law principles. ${ }^{102}$ It should be noted that this view was heavily criticised by the Court of Appeal in Problem Gambling. ${ }^{103}$ Finally, to this line of authority can be added an obiter comment from Thomas $\mathrm{J}$ in Vector Ltd $v$ Transpower New Zealand Ltd. ${ }^{104}$ In that case, Thomas J opined that the "unduly restrictive" Mercury formula could not have been intended to exclude illegality or

97 See Webster $v$ Auckland Harbour Board [1987] 2 NZLR 129 (CA) in contrast to New Zealand Stock Exchange $v$ Listed Companies Assoc Inc [1984] 1 NZLR 699 (CA); and Mai Chen "Accountability of SOEs and CrownOwned Companies: Judicial Review, the New Zealand Bill of Rights Act and the Impact of MMP" [1994] NZLJ 296.

98 Webster, above n 97, at 131. See also Webster v Auckland Harbour Board [1983] NZLR 646 (CA) at 646 and 650 .

99 Royal Australasian College of Surgeons v Phipps [1999] 3 NZLR 1 (CA) at 11.

100 At 11 .

101 Telco Technology Services Ltd v Ministry of Education [2014] NZHC 213 at [34].

102 At [37].

103 Problem Gambling, above n 2, at [48].

104 Vector Ltd v Transpower New Zealand Ltd [1999] 3 NZLR 646 (CA). 
improper purpose or motive as grounds for judicial review. ${ }^{105}$ To do so would put SOEs beyond the law. ${ }^{106}$

A contrary approach is to be found in New Zealand Stock Exchange v Listed Companies Assoc Inc. In Stock Exchange the Court of Appeal argued that it would be contrary to Parliament's intention to subject all decisions of corporate bodies established under statute to judicial review. ${ }^{107}$ Only decisions made pursuant to a particular statutory power would be subject to judicial review. ${ }^{108}$ In that case, the relationship between the Exchange and a listed company was held to lie in contract, and therefore the relevant decision was not the exercise of a particular statutory power. ${ }^{109}$ The Court of Appeal in Mercury adopted the same approach in holding that the Electricity Corporation's decision to terminate a contract was made in accordance with the common law of contract, and it was therefore not the exercise of a particular statutory power. ${ }^{110}$ The Court argued that in any event, the section relied upon by the claimants did not confer power upon the decision maker "in any true sense" and furthermore the section did not provide the ability to challenge such decisions through judicial review. ${ }^{111}$

\section{A Uniquely New Zealand Problem?}

The above analysis quite clearly discloses that the approach of the New Zealand courts to this issue diverges significantly. As a result, the law in this area lacks consistency and coherence. This Part briefly considers how the courts in England and Canada have approached this issue and concludes that it is a problem which courts in multiple jurisdictions have struggled to come to terms with. It is with this universality in mind that Part V argues that the lack of a consistent and coherent approach throughout the common law world has the same root cause: differing conceptions of the proper role of the courts in this area premised on different theories of the state.

The English approach to the justiciability of government contracting decisions provides equal complexity to the approach adopted in New Zealand. One commentator has suggested that the approach of the English courts has tended to confuse two different propositions. ${ }^{112}$ The first is the rejection of judicial review in situations where the claim lies purely in contract, but it is being pursued

105 At [85].

106 At [85].

107 Stock Exchange, above n 97, at 707.

108 At 707.

109 At 707

110 Mercury, above n 43, at 552.

111 At 560-561. See also Taggart, above n 43, at 346-348.

112 SH Bailey "Judicial Review of Contracting Decisions" (2007) PL 444 at 445. 
on public law grounds. ${ }^{113}$ The second proposition is that, in a contractual context, even if "fundamental public law principles" should apply, they are precluded by the contractual context. ${ }^{114}$ The English courts have tended to allow judicial review only in relation to decisions which contain a "public law element". ${ }^{115}$ However, the case law paints a rather confusing picture as to what qualifies as a public law element. The public law element has been held to exist in relation to the following decisions: the decision to terminate an individual's common law right to be a stallholder; ${ }^{116}$ the failure by a local authority to adhere to a specific policy relating to the retention or disposal of certain types of land; ${ }^{117}$ and the failure by a legal aid board to use a fair tender process in relation to a matter of significant public importance. ${ }^{118}$

Given the significant range of contexts seemingly providing a public law element, it is unsurprising that this approach has been criticised for being illogical and adding unnecessary and undesirable complication. ${ }^{119}$ A better approach was adopted in $R$ (on the Application of Molinaro) $v$ The Royal Borough of Kensington and Chelsea. ${ }^{120}$ In that case, Elias J held that authorities which are exercising a statutory function should in principle be subject to judicial review unless the complaint would undermine relevant private law principles. ${ }^{121}$ However, Molinaro has had limited application. Accordingly, the courts in England appear to have struggled with this issue to a similar extent to their New Zealand counterparts.

The Canadian courts do not appear to have fared much better. David Mullan, a leading commentator on administrative law in Canada, argued that "the law governing judicial review of procurement decisions in Canada is still in a state of turmoil or confusion". ${ }^{122}$ While not all government contracting decisions are procurement decisions, many of the issues raised in a

113 At 445 .

114 At 445 .

115 R (t/a Hammer Trout Farm) v Hampshire Farmers Markets Ltd [2003] EWCA Civ 1056 at [16].

$116 R$ v Barnsley Metropolitan Borough Council [1976] 1 WLR 1052 (CA) at 1052.

$117 R v$ Bolsover DC, ex parte Pepper (2001) 3 LGLR 20 (QB) at [33]. This is not unlike the majority approach in Ririnui, above n 1, at [48].

$118 R v$ Legal Aid Board, ex parte Donn [1996] 3 All ER 1 (CA) at 1-10.

119 Eleanor Aspey "The Search for the True Public Law element: Judicial Review of Procurement Decisions" 2016 PL 35 at 35; and Bailey, above n 112, at 444.

$120 R$ (on the Application of Molinaro) v The Royal Borough of Kensington and Chelsea [2001] EWHC 896 (Admin).

121 At [65] and [69]. See also Sue Arrowsmith "Judicial Review and the Contractual Powers of Public Authorities" (1990) LQR 277 at 291; Aspey, above n 119, at 42; and Bailey, above n 112, at 446.

122 David Mullan "The State of Judicial Scrutiny of Public Contracting in New Zealand and Canada" (2012) 43 VUWLR 173 at 189. 
procurement context apply equally to other forms of government contracting. The leading authority in this area, Shell Canada Products $v$ Vancouver (City), provides a number of reasons or principles for and against allowing judicial review. ${ }^{123}$ Air Canada $v$ Toronto Port Authority adopted a similar approach to the question of whether a matter is public, thus warranting judicial review, or private and thus excluded from judicial review. ${ }^{124}$ While a broad contextual approach does away with some of the rigidity of a strictly doctrinal approach, it also has the potential to result in inconsistent outcomes. An example of this is to be found when comparing 2169205 Ontario Inc (cob Lefroy Freshmart) $v$ Ontario (Liquor Control Board) with Dignam v New Brunswick Liquor Corp. In Lefroy a procurement process to select "agency stores" to run liquor outlets on behalf of the Canadian government was considered not to have engaged public interest issues, making judicial review unavailable. ${ }^{125}$ However, in Dignam, an application for judicial review almost indistinguishable from that in Lefroy succeeded on the basis of Shell. ${ }^{126}$

An analysis of the approaches adopted in England and Canada points strongly to the conclusion that the inconsistency and incoherence in this area of the law is not limited to New Zealand. The English approach could be usefully summarised as one which invites the courts to search for a public law element justifying the invocation of judicial review. ${ }^{127}$ The Canadian approach is not entirely dissimilar but tends to provide more guidance in the form of broad contextual tests. This inconsistency across jurisdictions raises the broader question of why the courts have struggled to develop a clear and consistent doctrinal approach to this issue. The article suggests that this is because the courts have conceptions of their role premised on differing theories of the state.

\section{A DICHOTOMY OF APPROACHES}

In considering whether matters involving government contracting are to be subjected to the court's supervisory jurisdiction by way of judicial review, the approach of the courts tends to fall into one of two categories: a narrow approach and a broad approach. Whether a court - or in some cases a particular judge - adopts a narrow or a broad approach is founded upon a conception of the proper role of the courts in this area, a conception which is premised on a theory of the state. The divergence in theories of administrative law among judges translates into a divergence in approaches to judicial review. This divergence is especially pronounced in the case of government contracting as the context is on the border between public and private law.

123 Shell Canada Products Ltd v Vancouver (City) [1994] 1 SCR 231 at 240-241.

124 Air Canada v Toronto Port Authority and Porter Airlines Inc 2011 FCA 347 at [60]

1252169205 Ontario Inc v Ontario (Liquor Control Board) [2011] ONSC 1878 at [30].

126 Dignam v New Brunswick Liquor Corp [2014] NBQB 109 at [33]-[35].

127 See Aspey, above n 119. 


\section{A Theory of Administrative Law}

Harlow and Rawlings state that "behind every theory of administrative law lies a theory of the state". ${ }^{28}$ Consistent with the apparent human need to classify things in order to make sense of them, a number of academics have attempted to organise theories of the state - and by implication, theories of administrative law - into categories or classes of thinking. Harlow and Rawlings draw on a traffic light metaphor to achieve this. ${ }^{129}$ So-called "red light theorists" favour strong judicial control of executive power, and consider administrative law to be the tool which prevents the "powerful engines of authority from running amok". ${ }^{130}$ Such an approach is argued to hark back to Diceyan conceptions of the rule of law and the equality principle. ${ }^{131}$ Those subscribing to a "red light theory" would argue for a broad role for judicial review in order to protect individual rights. ${ }^{132}$

In contrast, "green light theorists" consider administrative law not as responsible for placing a check on state power, but as a vehicle to assist the "administrative state" to implement collectivist policies. ${ }^{133}$ Green light theorists would prioritise democratic or political forms of accountability ahead of the undemocratic and unrepresentative courts. ${ }^{134}$ The role of judicial review would therefore be more limited and would consequently be available only in narrow circumstances. ${ }^{135}$

Placing theories of administrative law into neat categories through the use of a simple metaphor has understandably attracted significant criticism. ${ }^{136}$ Such a metaphor is of limited use. However, at a more generalised explanatory level, the cases explored in this article do point to a continuing reliance on administrative law ideology as the basis for either a narrow or a broad approach to judicial review. The judges who advocate a narrow approach to judicial review consistently raise similar arguments for so limiting judicial review which are premised on a green light theory of administrative law. In contrast, those advocating a broader approach similarly raise arguments which are loosely premised on a red light theory of administrative law.

128 Harlow and Rawlings, above n 7, at 1 .

129 At 1 .

130 At 23; and William Wade and Christopher Forsyth Administrative Law (9th ed, Oxford University Press, Oxford, 2004) at 4.

131 Harlow and Rawlings, above n 7, at 4-6.

132 At 31 .

133 At 31. See also HW Jones "The Rule of Law and the Welfare State" (1958) 58 Colum L Rev 143 at 151.

134 Harlow and Rawlings, above $n$ 7, at 37-38.

135 Adam Tomkins "In Defense of the Political Constitution" (2002) 22 OJLS 157 at 159.

136 Michael Taggart "Reinvented government, traffic lights and the convergence of public and private law. Review of Harlow and Rawlings: Law and Administration" [1999] PL 124 at 133; and Varuhas, above n 4, at 180 . 


\section{B The Narrow Approach}

Consistent with a green light theory of administrative law, a number of similar arguments have been drawn on by judges to justify a narrow approach to judicial review. These arguments fit broadly into two categories: arguments in favour of the "level playing field" approach; and arguments based on the idea that democratic and political accountability measures are better than the courts.

In a New Zealand context, several judges have adopted a "level playing field approach" in order to narrow the scope of judicial review. ${ }^{137}$ The approach argues that subjecting SOEs to public law burdens will place them at a competitive disadvantage to their privately owned equivalents. ${ }^{138}$ Justice William Young clearly adopted this approach in Ririnui in holding that the policy underlying s 4 of the SOE Act precludes judicial review of commercial decisions. ${ }^{139} \mathrm{He}$ argued that $\mathrm{s} 4$, which requires an SOE to be as profitable as comparable businesses not owned by the Crown, would be frustrated if the Court was to allow judicial review of such decisions. ${ }^{140}$ The same approach was adopted by Richardson $\mathrm{J}$ in the Court of Appeal in Mercury. ${ }^{141}$ There is further evidence of the level playing field approach in William Young J's analysis of s 21 of the SOE Act. He argued that if s 21 did not operate to preclude judicial review in relation to contracts entered into by SOEs, it would allow third parties to challenge contracts entered into by an SOE on grounds otherwise not available to other commercial parties, thus placing SOEs at a commercial disadvantage. ${ }^{142}$ Similarly, in Lab Tests the majority held that to place onerous procedural requirements on the DHB would "unduly fetter" its ability to effectively negotiate in a commercial environment. ${ }^{143}$ This argument is further reflected in a Canadian context through the courts' consideration of private discretion in Air Canada ${ }^{144}$ and the concern to ensure that freedom of contract was not unduly affected in Shell. ${ }^{145}$

Green light theorists see the courts as an obstacle to the efficient operation of the administrative state. ${ }^{146}$ Accordingly, they would argue for the use of political and democratic accountability

137 Taggart, above n 43, at 353; and Michael Taggart "The Impact of Corporatisation and Privatisation on Administrative Law" (1992) 51 AJPA 368 at 370.

138 Taggart, above $\mathrm{n} 43$, at 353 .

139 Ririnui, above n 1, at [231].

140 At [217] and [231]. See also Post Office Bank Ltd, above n 43, at 14.

141 Mercury, above n 43, at 558-560.

142 Ririnui, above n 1, at [231].

143 Lab Tests, above n 62, at [78].

144 Air Canada, above n 124, at [60].

145 Shell, above n 123, at [240].

146 Harlow and Rawlings, above n 7, at 37. 
measures in lieu of the courts. ${ }^{147}$ This point was made in Lab Tests where it was held that - in this context - other accountability measures would generally be more appropriate than the courts. ${ }^{148}$ In the High Court in Mercury, Barker J argued that judicial review's special procedural requirements would retard the speedy determination of what was essentially a commercial dispute. ${ }^{149}$ Consistent with this approach, a number of judgments have highlighted the availability of alternative accountability mechanisms in arguing for a narrow scope of review. These have included ministerial and parliamentary oversight; ${ }^{150}$ the resumption provisions under the Treaty of Waitangi Act $1975 ; 151$ the Ombudsman; ${ }^{152}$ the Auditor-General; ${ }^{153}$ and accountability of directors to shareholders. ${ }^{154}$ In a similar vein, the courts have shown concern about the appropriateness of public law remedies. In Ririnui William Young J argued that judicial review would not be appropriate where criminal and civil remedies are available. ${ }^{155}$ Similarly, in Problem Gambling the Court refused to entertain the Foundation's application for review as it was merely a disappointed commercial party trying to use public law remedies in a commercial context. ${ }^{156}$ Finally, another concern raised by William Young $\mathbf{J}$ in Ririnui and echoed by others is the potential for a significant increase in litigation should the scope of review be broadened. This is a common "forum shopping" type argument which William Young J described as "gaming litigation". ${ }^{157}$ The negative public implications of excessive litigation were similarly identified in Shell. ${ }^{158}$

\section{The Broad Approach}

It has been argued that the shift towards new public management and a reduced state would consequently result in the "rolling back" of judicial review as a cause of action. ${ }^{159}$ Such a reduced

147 At 38; and Tomkins, above n 135, at 159.

148 Lab Tests, above n 62, at [59]. See also Mercury, above n 43, at 559.

149 Auckland Electric Power Board v Electricity Corporation of New Zealand Ltd [1993] 3 NZLR 53 (HC) at 61.

150 Lab Tests, above n 62, at [59]; Ririnui, above n 1, at [198]; and Problem Gambling, above n 2, at [50].

151 Ririnui, above n 1, at [219]-[220].

152 At [205]; and Problem Gambling, above n 2, at [50].

153 Ririnui, above n 1, at [200]; and Problem Gambling, above n 2, at [50].

154 Mercury, above n 1, at 388.

155 Ririnui, above n 1, at [214].

156 Problem Gambling, above n 2, at [42]. See also Mercury, above n 1, at 391; and Air Canada, above n 124, at [60].

157 Ririnui, above n 1, at [214].

158 Shell, above n 123, at [240].

159 McLean, above n 4; and Taggart, above n 137, at 368. 
role for the courts would be very concerning for red light theorists. However, this shift has simply resulted in judges coming up with creative ways to justify a broader approach to judicial review. The main way this has been achieved is through the use of arguments which centre on some broader public interest or public law element. Put another way, red light theorists have used the public interest as a proxy to justify a broad approach to judicial review.

The best example of this approach is to be found in the majority judgment in Ririnui. In that case, the majority went to significant lengths to establish a public interest implication, and thus circumvent the general proposition in Mercury. ${ }^{160}$ This is to be contrasted with William Young J's approach which went to equal lengths to justify a narrow approach to judicial review. Further evidence of this approach in New Zealand is to be found in Problem Gambling. In light of Ririnui, the Court of Appeal in Problem Gambling held that where a claimant is seeking to protect the public interest in an application for judicial review, the court may adopt a broader scope of review in order to protect that interest. ${ }^{161}$ Woodhouse $\mathrm{J}$ adopted a similar approach in the High Court in arguing that the starting point in such matters is context; it is not the general proposition in Mercury, subject to context. ${ }^{162}$ In Phipps the relevance of the public interest was reflected in the Court's willingness to use judicial review to enquire into matters which have important public consequences. ${ }^{163}$ Similarly, in Webster the Court of Appeal suggested that in exercising its contracting powers, a public body might be constrained by its public law responsibilities, and in particular, the need to consider public interest factors when exercising contracting powers. ${ }^{164}$

There is further evidence of such an approach in both England and Canada. The English approach - as outlined in Hammer Trout Farm - relies on the existence of something with the character or flavour of public law to justify judicial review. ${ }^{165}$ Suggestions as to what constitutes this public law element have included: ensuring public bodies follow good administrative practice, especially in the case of matters of vital public importance, ${ }^{166}$ protecting common law rights; ${ }^{167}$ and, respecting public policy. ${ }^{168}$ In Canada, the courts have drawn on a number of public interest factors to justify a broad

160 Ririnui, above n 1, at [71].

161 Problem Gambling, above n 2, at [42].

162 Problem Gambling, above n 70, at [63].

163 Phipps, above n 99, at 11.

164 Webster, above n 97, at 646 and 650 .

165 Hammer Trout Farm, above n 115, at [16].

$166 R v$ East Berkshire Health Authority (Ex parte Walsh) [1985] QB 152 (CA) at 164; and Donn, above n 118, at 11 .

167 Barnsley, above n 116, at 1056.

168 Pepper, above n 117, at [33]. 
approach to judicial review. These have included: public concerns about equality of access to government markets; integrity in the conduct of government business and the promotion of community values; the use of public funds; ${ }^{169}$ the carrying out of significant public projects; $;{ }^{170}$ and, what was described in Air Canada as an "exceptional" category of cases, where the conduct engages a serious public dimension. ${ }^{171}$

\section{CONCLUSION}

This article has considered two recent developments in the case law concerning the justiciability of government contracting decisions. In Ririnui the majority of the Supreme Court provided an exception to the Mercury criteria by holding that not all commercial decisions will be reviewable on the narrow bases of fraud, corruption and bad faith. The majority did not define which decisions are likely to fall outside of the general proposition save to say that the case before the Court was excepted on the basis that it contained a substantial public interest component. This has likely opened the door to a broader role for judicial review in this context. In Problem Gambling the Court of Appeal added a further contextual factor to those outlined in Lab Tests. Justice Arnold held that as part of the contextual analysis, the courts must consider the nature of the interest that the claimant is seeking to protect. ${ }^{172}$ Where that interest is public in nature, the courts may be justified in adopting a broader scope of review to protect that interest. ${ }^{173}$

Despite these developments, the law in this context remains inconsistent and incoherent. This is neither a contemporary issue, nor one which is limited to a New Zealand context. The article suggests that this lack of coherence and consistency is due to a court's approach to this issue being ultimately dependent on that court's normative conception of its role in this area, a conception which is premised on a theory of the state. As a result, the courts have tended to take either a narrow or a broad approach to judicial review. Those courts which subscribe to a green light theory of the state accordingly raise a number of similar arguments to justify a narrow approach to judicial review. In contrast, those courts subscribing to a red light theory raise similar arguments justifying a broader role.

This normative butting of heads is especially pronounced in a government contracting context because it is an issue which sits on the border of the "nebulous line" between public and private law. ${ }^{174}$ Some suggest that the distinction between public and private law is meaningless, and that attempting

169 Shell, above n 123, at 240; and Bot Construction Ltd v Ontario (Minister of Transportation) (2009) 99 OR (3d) 104 (Div Ct) at [24].

170 Bot Construction, above n 169, at [24].

171 Air Canada, above n 124, at [60].

172 Problem Gambling, above n 2, at [42].

173 At [42].

174 Taggart, above n 137, at 369. 
to organise the law through the use of neat normative schemes could distort thinking about this issue. $^{175}$

The courts have certainly not ignored this and other normative schemes in deciding whether or not to allow judicial review in a given case. In fact, they have relied on them.

Others have suggested that the courts can resolve the issue by drawing on values in common to both public and private law which will be capable of bridging the divide, ${ }^{176}$ or by developing a "law of public contracts". ${ }^{177}$ However, the New Zealand courts are still some way off reaching this point. Admittedly, the justiciability of government contracting decisions is a vexing issue. However, the New Zealand courts need to stop hiding behind an inconsistent doctrine and recognise that cases are ultimately being decided according to that court's normative conception of the role of judicial review in this area.

175 Varuhas, above n 4, at 177. See also Elliott, above n 3, at 82; and Carlow Harlow "'Public' and 'Private' Law: Definition without Distinction" (1980) 43 MLR 241 at 242.

176 Harlow and Rawlings, above n 7, at 21.

177 Anne Davies "English law's treatment of government contracts: The problem of wider public interests" in Freedland and Auby (eds) The Public-Private Divide - Une Entente Assez Cordiale? (Hart Publishing, Oxford, 2006) 113 at 113. 
